\title{
FLOT1 Gene
}

National Cancer Institute

\section{Source}

National Cancer Institute. FLOT1 Gene. NCI Thesaurus. Code C122747.

This gene may be involved in the structure of caveolae. 